\title{
2004s-03 \\ The Living Arrangement Dynamics of Sick, Elderly Individuals
}

\author{
Benoit Dostie, Pierre Thomas Léger
}

\begin{tabular}{c}
\hline Série Scientifique \\
Scientific Series
\end{tabular}

\section{Montréal \\ Janvier 2004}

(C) 2004 Benoit Dostie, Pierre Thomas Léger. Tous droits réservés. All rights reserved. Reproduction partielle permise avec citation du document source, incluant la notice $\mathbb{C}$.

Short sections may be quoted without explicit permission, if full credit, including (C notice, is given to the source.
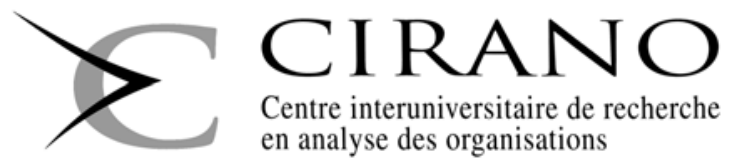

Centre interuniversitaire de recherche

en analyse des organisations 


\section{CIRANO}

Le CIRANO est un organisme sans but lucratif constitué en vertu de la Loi des compagnies du Québec. Le financement de son infrastructure et de ses activités de recherche provient des cotisations de ses organisations-membres, d'une subvention d'infrastructure du ministère de la Recherche, de la Science et de la Technologie, de même que des subventions et mandats obtenus par ses équipes de recherche.

CIRANO is a private non-profit organization incorporated under the Québec Companies Act. Its infrastructure and research activities are funded through fees paid by member organizations, an infrastructure grant from the Ministère de la Recherche, de la Science et de la Technologie, and grants and research mandates obtained by its research teams.

\section{Les organisations-partenaires / The Partner Organizations}

PARTENAIRE MAJEUR

. Ministère du développement économique et régional [MDER]

PARTENAIRES

. Alcan inc.

. Axa Canada

. Banque du Canada

. Banque Laurentienne du Canada

. Banque Nationale du Canada

. Banque Royale du Canada

. Bell Canada

. BMO Groupe Financier

. Bombardier

. Bourse de Montréal

- Caisse de dépôt et placement du Québec

. Développement des ressources humaines Canada [DRHC]

. Fédération des caisses Desjardins du Québec

. GazMétro

. Hydro-Québec

. Industrie Canada

. Ministère des Finances [MF]

. Pratt \& Whitney Canada Inc.

. Raymond Chabot Grant Thornton

. Ville de Montréal

. École Polytechnique de Montréal

. HEC Montréal

. Université Concordia

. Université de Montréal

. Université du Québec à Montréal

. Université Laval

. Université McGill

Associe A :

. Institut de Finance Mathématique de Montréal (IFM²)

. Laboratoires universitaires Bell Canada

. Réseau de calcul et de modélisation mathématique $\left[\mathrm{RCM}^{2}\right]$

. Réseau de centres d'excellence MITACS (Les mathématiques des technologies de l'information et des systèmes complexes)

Les cahiers de la série scientifique (CS) visent à rendre accessibles des résultats de recherche effectuée au CIRANO afin de susciter échanges et commentaires. Ces cahiers sont écrits dans le style des publications scientifiques. Les idées et les opinions émises sont sous l'unique responsabilité des auteurs et ne représentent pas nécessairement les positions du CIRANO ou de ses partenaires.

This paper presents research carried out at CIRANO and aims at encouraging discussion and comment. The observations and viewpoints expressed are the sole responsibility of the authors. They do not necessarily represent positions of CIRANO or its partners.

ISSN 1198-8177 


\title{
The Living Arrangement Dynamics of Sick, Elderly Individuals
}

\author{
Benoit Dostie ${ }^{\dagger}$, Pierre Thomas Léger
}

\begin{abstract}
Résumé / Abstract
Dans cet article, nous étudions la dynamique des choix d'habitation des personnes âgées en manque d'autonomie. En utilisant les données provenant du Panel Study of Income Dyamics et de son Parental Health Supplement, nous sommes en mesure de reconstruire l'historique complet des choix d'habitation de ces individus. La méthodologie utilisée pour tenir compte de l'impact des caractéristiques démographiques, de l'état de la santé et de la situation financière des personnes âgées sur leur choix d'habitation consiste en une série de modèles de risques concurrents à effets aléatoires simultanés. Cette méthodologie permet aussi de tenir compte de la dépendance à la durée et à l'état ainsi que de l'hétérogénéité non-observée. Nous trouvons que ces derniers phénomènes sont très importants pour prédire le mode d'habitation choisi par ce segment de la population.
\end{abstract}

Mots clés : Dynamique des choix d'habitation, risques concurrents, modèle markovien, hétérogénéité non-observée, vieillissement des populations.

In this paper, we address the dynamics associated with living-arrangement decisions of sick, elderly individuals. Using data from the Panel Study of Income Dynamics and its Parental Health Supplement, we construct the complete living-arrangement histories of elderly individuals in need of care. We use a simultaneous random-effects competing-risks model to analyze the impact of demographic characteristics, health and wealth on the livingarrangement decisions of sick elderly individuals while taking into account state and duration dependence as well as unobserved heterogeneity. We find that state and duration dependence serve as important predictors for the living arrangement choices of sick elderly individuals.

Keywords: Living arrangement dynamics, competing risks, markov models, unobserved heterogeneity, aging.

Codes JEL : J14, C41, I10.

\footnotetext{
${ }^{*}$ The authors gratefully acknowledge the financial support of the Ministère des Finances, de l'Économie et de la Recherche du Québec. We are also grateful to seminar participants at McGill, Laval, SCSE (Montréal), CEA (Ottawa), $4^{\mathrm{e}}$ Journée d'économie publique LAGV (IDEP-Marseilles), CHESG (Banff) and HER0 ASSA Meetings (San Diego).

${ }^{\dagger}$ Address: Institute of Applied Economics, HEC Montréal, 3000, chemin de la Côte-Sainte-Catherine, Montréal, H3T 2A7; e-mail: benoit.dostie@hec.ca; fax: 514-340-6469; phone: 514-340-6453; CIRANO, CIRPÉE and IZA. $\$$ Corresponding author. Address: Institute of Applied Economics, HEC Montréal, 3000, chemin de la CôteSainte-Catherine, Montréal, H3T 2A7; e-mail: ptl@hec.ca; fax: 514-340-6469; phone: 514-340-6436; CIRANO and CIRPÉE.
} 


\section{Introduction}

The demographic trend of an increasing elderly population, both in absolute and relative terms, has put considerable upward pressure on medical and long-term-care expenditures. Although many sick elderly individuals rely on nursing-home and formal in-home care, most rely on informal care provided by family members, including spouses and children. ${ }^{1}$ Not surprisingly, a growing body of literature has examined the factors that affect the mode-of-care and living-arrangement decisions. More specifically, many studies have examined the role of family composition, health/disability, income and wealth, as well as family bargaining on the living-arrangement decisions of sick elderly individuals, i.e. on the decision to live independently (with or without a spouse), cohabit with a family member, or move into a nursing home. ${ }^{2}$

The literature, however, has generally ignored the long-term dynamics within and across different living arrangements by modelling (implicitly or explicitly) the living-arrangement decisions as once-and-for-all, or, as a series of decisions which are made independently from one another; this in spite of the fact that sick elderly individuals often experience more than one type of living arrangement. ${ }^{3}$ Furthermore, prior living arrangements, as well as their lengths, likely influence future living-arrangement choices. For example, simple examination of the transition histories show that sick elderly individuals often follow a cohabiting living arrangement with a nursing home stay. Thus, treating different living arrangements as simple substitutes without examining the dynamics between them is omitting a potentially important element.

In this paper, we address the dynamics associated with living-arrangement decisions of sick

\footnotetext{
${ }^{1}$ A fact highlighted in many studies including Stoller (1983), White-Means (1992) Kotlikoff and Morris (1990), and Börsch-Supan, Gokhale and Kotlikoff and Morris (1991).

${ }^{2}$ See for example Greenberg and Ginn (1979), Branch and Jett (1982), Cohen, Telland and Wallack (1986), Garber and MaCurdy (1989), Börsch-Supan, Kotlikoff and Morris (1991) Stern (1995), Pezzin and Schone (1999) Hidemann and Stern (1999), and Engers and Stern (2002).

${ }^{3}$ Heiss, Hurd and Börsch-Supan (2003) examine the relationship between living arrangements, health and economic status. However, their approach which estimates transition probabilities can not control for unobserved heterogeneity and duration dependence. Their approach also assumes that outcome probabilities of the state variables are conditionally independent. Finally, because the initial sample contained non-institutionalized elderly individuals exclusively, transitions into and out of nursing homes are limited.
} 
elderly individuals. We first construct complete living-arrangement histories using the Panel Study of Income Dynamics (PSID) and its Parental Health Supplement (PHS) on elderly individuals in need of care. We then formulate an explicit model of the living-arrangement transitions' generating process. Because the model must account for living-arrangement states at every moment in time, and because transitions can occur at any time, we use a simultaneous random-effects competingrisks model. Transition intensities are modelled in a very flexible manner with respect to the baseline hazard using the Gompertz distribution for durations in each state. Finally, since we observe an individual through multiple living arrangements, we control for individual unobserved heterogeneity assuming stochastic variation in the transition rates.

Our econometric framework allows us to simultaneously estimate state-specific duration dependence which provides information on the stability of each living arrangement; something that has, to our knowledge, not been done before. If duration dependence is an important element in the living-arrangement decisions of sick elderly individuals, then public policies may be more effective if they are developed accordingly. We are also able to verify whether or not previous results with respect to the impact of demographic, income and health factors on living-arrangement decisions are robust to duration dependence, unobserved heterogeneity and the competing risks of transitions into other types of living arrangements, death or censoring.

Results presented below underscore, among other things, the importance of age, state and duration dependence in the living-arrangement decisions of sick elderly parents. For example, we show that although individuals are more likely to transit out of cohabitation as they grow older, they are less likely to transit back to independent living as the time spent in cohabitation increases. Furthermore, transitions out of nursing home exhibit negative duration dependence for both transitions to independent living and cohabitation. That is, individuals are less and less likely to ever exit a nursing home as the time spent in such a living arrangement increases. Results such as these suggest that public policies may be more effective if they are targeted towards particular individuals. For example, a policy which seeks to encourage the de-institutionalization of elderly 
individuals in favor of alternate forms of care (such as cohabitation) may be more effective if it is targeted at elderly individuals in the early periods of their nursing-home stay.

The remainder of the paper is organized as follows. In section 2 we present details of the data set and summary statistics on living-arrangement transitions and durations. In section 3 we develop the econometric model. Results are presented in section 4. Conclusions are drawn in section 5.

\section{Data and Summary Statistics}

The data used in this paper are drawn from the Panel Study of Income Dynamics' Parental Health Supplement of 1991. In 1988, PSID households were asked some basic questions about their parents (living and/or deceased). This initial information formed the basis of the Parental Health Supplement which was administered to PSID households in 1991. Eligibility for the PHS required that the parent of the PSID Head of household (or spouse): (i) was 70 years of age or older in 1991, or (ii) had died after 1980 at 70 years of age or older (in the case of a deceased parent). The PHS includes 1,650 eligible 'fathers' and 2,008 eligible 'mothers'. ${ }^{4}$

In an attempt to identify parents who were in need of care/assistance, the PSID head of household (and spouse) was asked if their parent(s) had reached the point where they could no longer be expected to live independently and take care of their own daily needs without extra help, at any time between 1975 and 1991 (we henceforth refer to the time when the parent reached such a point as the parent's 'time-of-illness'). For 1,650 eligible fathers, 431 of their children identified them as having reached such a needs threshold at 60 years of age or older. Similarly, the children of 588 of 2,008 eligible mothers identified them as having reached such a needs threshold at 60 years of age or older. These 1,019 individuals constitute the sample we use for the remainder of the paper.

If a parent had reached such a 'needs' threshold, a retrospective questionnaire was administered to the adult child about each parent (we henceforth refer to these parents as 'sick elderly individ-

\footnotetext{
${ }^{4}$ Fathers may either be the PSID Head of household's father or the spouse's father. Similarly, mothers may either be the PSID Head of household's mother or the spouse's mother. Thus, each PSID family may have at most 4 parents who qualify for the Parental Health Supplement.
} 
uals'). Information was collected about: (i) whether the parent suffered from a series of particular illnesses; (ii) whether the parent was able to perform a series of basic tasks; (iii) where the parent resided (and for how long); (iv) how many living children the parent had; (v) parental home ownership; and (vi) parental age and marital-status. This information was collected for various points in time during the parent's history. Because dates were given for each parent's transition from one type of living arrangement to another (as well as information collected about the parent and his or her family at the time of each transition), we are able to construct the full living-arrangement history of each parent up to their death or up to $1991 . .^{5,6}$ As a result, the PHS lends itself well to both the analysis of parental living-arrangement decisions as well as their durations.

As in the previous literature, we focus on 3 different types of living arrangements: (i) independent living with or without a spouse ${ }^{7}$; (ii) cohabiting with a family member (for example, with a child or child-in-law); and (iii) living in a nursing home. Summary statistics on the living-arrangements at the time-of-illness for fathers and mothers (including information on their lengths) are presented in Tables 1 and 2, respectively. At the time-of-illness, 24.6 per cent of fathers entered a nursing home, 22.3 per cent of fathers moved-in with a child (cohabitation), while 42 per cent of fathers remained in independent living. ${ }^{8}$ Although some fathers remain in these living arrangements until their death (or until they are censored in 1991), many others experience subsequent transitions into other types of living arrangements. The full living-arrangement histories of fathers are summarized in Figure 1.

Mothers in the PHS appear to behave differently from fathers. For example, of the mothers

\footnotetext{
${ }^{5}$ Although recall based survey data may often exhibit measurement error, studies have shown that the accuracy of such data is good for important events such as marital, fertility and major employment episodes (Dex, 1991). Given that the survey questions in our data set are centered around major events (i.e., living-arrangement transitions of elderly parents), recall is unlikely to be an important issue.

${ }^{6}$ Of the 431 fathers 'in-need', 308 had died prior to, or in, 1991. As a result, we observe the full living-arrangement history of 70 per cent of the fathers in our sample; the rest being censored in 1991. Similarly, 55 per cent of mothers 'in-need' have complete living-arrangement histories; the rest being censored.

${ }^{7}$ In this type of living arrangement, some received formal in-home care, while other received informal in-home care provided by family and friends including spouses and children.

${ }^{8}$ The rest of the fathers (10,9 per cent) entered a hospital at the time of illness, where they remained until their death or until 1991. We exclude hospital stays as a type of living arrangement in our econometric analysis below.
} 
in-need, 31.3 per cent entered a nursing home (compared to 24.3 per cent of fathers) at the timeof-illness. This somewhat larger proportion may be partially due to the fact that women often outlive their spouse and are thus unable to benefit from a potentially important source of care. Furthermore, 37.9 per cent of mothers moved in with someone (cohabit) at the time-of-illness, while 24.4 per cent of mothers remained in independent living at that time. ${ }^{9}$ Again, the fact that mothers appear to rely more heavily on cohabitation and are less likely to remain independent may be due to the lack of a healthy/living spouse for caregiving. The full-living arrangement histories of mothers are summarized in Figure 2.

Another important element in the above figures is the percentage of individuals who transit out of an initial living arrangement. For example, in our sample, 13 per cent of fathers and 10.3 per cent of mothers are observed transiting out of an initial nursing-home stay. It is, however, important to note that a large proportion of both fathers and mothers are censored in nursing-home care, i.e., we do not observe whether or not they ultimately transit out of nursing-home care. Thus the percentage of actual transitions out of an initial nursing-home stay is likely to be greater. Transitions out of an initial cohabiting or independent living arrangement are, not surprisingly, more common. For example, 24 per cent of fathers and 20.4 per cent of mothers are observed transiting out of an initial cohabiting stay. Consequently, even in the presence of censoring, a considerable percentage of individuals transit out of their initial living arrangement. Another important element that should be highlighted in these figures is the means by which individuals ultimately end up in a particular living arrangement. For example, many individuals enter a nursing home via cohabitation. As a result, cohabitation may serve both as a substitute and a lead-in to institutionalization. These initial results not only indicate that living-arrangement decisions may be made more than once but also suggest that they are not independently made from one another.

Duration data (presented in Tables 1 and 2) show that mothers experience considerably longer

\footnotetext{
${ }^{9} 6.9$ per cent of the mothers entered a hospital at the time illness, where they remained until their death or until 1991.
} 
lengths of stays across all types of living arrangements. For example, if we compare the three different living arrangements (excluding hospital stays) for mothers and fathers who died in their first living arrangement, we find that mothers have a much longer average length of stay - in nursing home (1,265 days compared to 897); cohabitation (1,414 days compared to 761.9); and independent living (1,645 days compared to 973). Women may have longer nursing-home and cohabiting stays because they live longer and are more likely to outlive their spouse (or because male spouses may be less able or willing to care for their ailing wives). They might also have longer independent-living durations because they are better able to care for themselves without the full time use of informal and formal care.

Table 3 provides labels for variables (covariates) that are used in our analysis while Table 4 presents summary statistics for these covariates by transition types, i.e., for each possible type of exit. As is apparent, the mean value for a given covariate varies greatly by transition type. To cite just one example, elderly parents who transit from independent living to cohabitation, have on average more children than those who remain in independent living, yet have less children than those who transit from independent living to nursing home. Because the role of covariates appears to be transition-type specific (i.e., entry-exit pair specific), we adopt an econometric model that takes into account the different types of transitions in order to model the living-arrangement choices correctly.

\section{Econometric Specification}

In order to analyze the impact of demographic characteristics, wealth, health, unobserved heterogeneity and duration dependence on the living-arrangement decisions of the sick elderly, we use a simultaneous random-effects competing-risks model. ${ }^{10}$ We extend the basic duration model to a competing-risks framework to take into account multiple types of transitions (transitions from one

\footnotetext{
${ }^{10}$ Another option would be to use a structural dynamic programming approach.
} 
particular type of living arrangement to another type of living arrangement, death or censoring). ${ }^{11}$ Because we observe the complete living-arrangement histories, we estimate a competing-risks model for each possible state. Simultaneity between the competing-risks models is achieved by including an individual-specific random-effects component that also takes into account unobserved heterogeneity. We use likelihood based methods to estimate the model by making assumptions about the probability density function of duration within each state and about the random effects.

This simultaneous random-effects competing-risks model can be interpreted as a finite-state continuous-time Markov model (Lancaster (1990)). To see this, let $Y(t)$ represent the state of the individual at time $t . Y(t)$ can take 4 values : (1) living in a nursing home, (2) living independently (3) cohabiting, and (4) death. Transitions between states are determined by a matrix of transition intensities. That is, given that state $b(b \in\{1,2,3\})$ is entered at calendar time $t$ and is still occupied at $t+s$, the transition out of $b$ is determined by the set of 3 transition intensities $h_{b e}(t, s)$ (where $e \in\{1,2,3,4\}$ and $e \neq b$ ). As a consequence, $h_{b e}(t, s) d s$ gives the probability of a departure from state $b$ to state $e$ in the short interval from $t+s$ to $t+s+d s$. This probability is conditional on occupation of $b$ for $s$ and on the previous transition history. It is also conditional on the level and time paths of regressor vectors to $t+s$. The matrix of transition intensities between the 4 states takes the form

$$
\left[\begin{array}{cccc}
1-h_{1} & h_{12} & h_{13} & h_{14} \\
h_{21} & 1-h_{2} & h_{23} & h_{24} \\
h_{31} & h_{32} & 1-h_{3} & h_{34} \\
0 & 0 & 0 & 1
\end{array}\right]
$$

where we define

$$
h_{b}(t)=\sum_{\substack{b \neq e \\ e}} h_{b e}(t)
$$

to be the probability of exiting state $b$. This decomposition allows us to not only study the factors determining the length of stay in a particular living arrangement but also compare the different

\footnotetext{
${ }^{11}$ See Crowder (2001) for a general treatment of competing-risks models or Dolton and van der Klaauw (2001) and Maelli and Pudney (1996) for detailed recent examples.
} 
factors behind different types of exits. ${ }^{12}$

To build the likelihood function, we assume the that probability density function of the time spent in each living arrangement takes the generalized Gompertz form. We choose the generalized form for two reasons. First, it allows for piecewise-linear duration splines in the baseline hazard. As a result, we do not make any assumptions about the form of duration dependence present in our data. Second, the Gompertz distribution gives rise to a very convenient form for the hazard rates or transition intensities : the log-hazards are linear in the covariates of interest. ${ }^{13}$

Specifically, we let the transition from living arrangement $b$ to living arrangement $e$ take the following form:

$$
\ln h_{b e}^{i}\left(t \mid x_{i}, z_{i t}\right)=\gamma_{0}^{b e} \text { time }_{t}+\gamma_{1}^{b} \text { age }_{i t}+\beta_{0}^{b e}+\beta_{1}^{b e} x_{i}+\beta_{2}^{b e} z_{i t}, \quad b, e=1,2, \ldots, 4, \quad b \neq e
$$

where the vector $x_{i}$ includes person-specific variables such as gender and the vector $z_{i t}$ includes timevarying spell-specific variables such as health or marital status. As noted previously, a complete description of the variables included in the econometric analysis is provided in Table 3.

It is important to note that the hazard incorporates two different types of duration dependence: age and living-arrangement duration dependence. These two effects are separately identifiable because the duration clock is reset to zero after a transition whereas the age clock is not. In both

\footnotetext{
${ }^{12}$ One could interpret each line of the transition matrix as describing a competing-risk model where there is a number of latent survival times, one for each destinations, and the actual destination observed is the minimum of the latent survial times.

${ }^{13}$ We say that $t$ follows the Gompertz distribution when its density function takes the form:

$$
f(t)=e^{(\lambda+\gamma t)-\frac{e^{\lambda}}{\gamma}\left(e^{\gamma t}-1\right)}
$$

The survivor function is

$$
S(t)=e^{\frac{-e^{\lambda}}{\gamma}\left(e^{\gamma t}-1\right)}
$$

and the hazard rate is written as

$$
h(t)=e^{\lambda} e^{\gamma t}
$$

or

$$
\ln h(t)=\lambda+\gamma t
$$

The model is implemented by parametrizing $\lambda=\beta X$. Thus, in its most basic form, we write a Gompertz hazard as

$$
\ln h(t)=\gamma T(t)+\beta X
$$
}


cases, we use a piecewise-linear splines to allow for the most general form of duration dependence possible. For a duration spline $T(s)$ with $P$ nodes, we have

$$
T(s)=\left(\begin{array}{c}
\min \left[s, p_{1}\right] \\
\max \left[0, \min \left[s-p_{1}, p_{2}-p_{1}\right]\right] \\
\cdots \\
\max \left[0, \min \left[s-p_{P-1}, p_{P}-p_{P-1}\right]\right] \\
\max \left[0, s-p_{P}\right]
\end{array}\right)
$$

where $p_{1}, \ldots, p_{P}$ represent the nodes. To identify the nodes, we first divide each duration into separate time intervals of equal length and estimate separate duration-dependence coefficients for each interval. When two duration-dependence estimates are equal to each other, we merge the two time intervals. Although theoretically possible, we do not add calendar time to our model as we do not observe enough transitions to differentiate its impact from the impact of age. It would also be possible to let the impact of age differ across transition types. However, estimation results do not reject the hypothesis that $\gamma_{1}^{b e}=\gamma_{1}^{b}, \forall e$. As a result, we henceforth assume $\gamma_{1}^{b e}=\gamma_{1}^{b}, \forall e$.

Then, if we observe a sick elderly individual $i$ through $C_{i}$ cycles $\left(C_{i}=2\right.$ or 3$)$, his or her contribution to the log likelihood will be

$$
L_{i}=\sum_{c=1}^{C_{i}} \sum_{b=1}^{3} \sum_{e=1}^{4} d_{b}\left[m_{e}^{i} \log h_{b e}^{i}\left(t^{i}\right)-\Lambda_{b}\left(t^{i}\right)\right]
$$

where the integrated hazard takes the familiar form

$$
\Lambda_{b}(t)=\int_{0}^{t} \sum_{\substack{e \\ b \neq e}} h_{b e}(t) d t ; \quad b, e=1,2, \ldots, 4, \quad b \neq e
$$

and where the two sets of binary indicators are defined as follow

$$
\begin{aligned}
& d_{b}=\left\{\begin{array}{lc}
1 & \text { if } b \text { is entered at the beginning of the cycle } \\
0 & \text { otherwise }
\end{array}\right. \\
& m_{e}=\left\{\begin{array}{lc}
1 & \text { if } e \text { is occupied at the end of the cycle } \\
0 & \text { otherwise }
\end{array}\right.
\end{aligned}
$$

For a censored observation, $d_{e}=0, e=1, \ldots, 4$. Hence its contribution to the likelihood is simply

$$
\exp \left(-\Lambda_{b}(t)\right)
$$


Note that some transition intensities may be identically zero (i.e. transitions out of absorbing states). We next discuss two potential issues that must be addressed when estimating these types of duration models.

(i) Initial conditions Usually, the likelihood function is conditional on the initial state and on the state history prior to the start of the observation. However, there is no initial conditions problem in our data as everyone begins in independent living.

(ii) Unobserved heterogeneity In order to account for potential unobserved heterogeneity, we assume that the hazard rate depends on a random person-specific effect $\theta_{i}$ (where $\theta_{i}$ can be interpreted as a person-specific taste for change). Consequently, we rewrite the conditional hazard as

$$
\ln h_{b e}^{i}\left(t \mid x_{i}, z_{i t}\right)=\gamma_{0}^{b e} \text { time }_{t}+\gamma_{1}^{b} \text { age }_{i t}+\beta_{0}^{b e}+\beta_{1}^{b e} x_{i}+\beta_{2}^{b e} z_{i t}+\theta_{i}, \quad b, e=1,2, \ldots, 4, \quad b \neq e .
$$

We assume $\theta_{i}$ to be distributed normally with mean 0 and variance $\sigma_{\theta}$. Thus, $\theta_{i}$ is independent of the values of any regressor at that time. We identify the variance $\left(\sigma_{\theta}\right)$ through the observation of the same individual across multiple types of living arrangements. The likelihood function is built in the same manner as before. Estimation is done by maximizing the marginal likelihood, integrating out the heterogeneity components $\theta_{i}$ :

$$
\mathcal{L}_{i}\left(\gamma, \beta, \sigma_{\theta} \mid \text { time }_{t}, \text { age }_{i t}, x_{i}, z_{i t}\right)=\int_{-\infty}^{+\infty} \prod_{c=1}^{C_{i}} \mathcal{L}\left(\gamma, \beta, \sigma_{\theta} \mid \text { time }_{t}, \text { age }_{i t}, x_{i}, z_{i t}, \theta_{i}\right) f\left(\theta_{i}\right) d \theta .
$$

We use Gauss-Hermite Quadrature to approximate the normal integral.

\section{Results}

Results with respect to coefficients describing the living arrangement dynamics are summarized in Tables 5 and 6 . Table 7 , which is divided into 3 parts, presents coefficients for other covariates of interest for transitions out of independence, cohabitation and nursing home, respectively. Because we 
find unobserved heterogeneity to be significant $\left(\sigma_{\theta}=1.21\right.$ with a standard error of 0.11$)$, all tables include results without (column "Base") and with (column "Mixed") unobserved heterogeneity.

\subsection{Transitions out of Independence}

We first examine estimation results for elderly individuals whose current living arrangement is independent living. In the first row of Table 5, we find that growing older significantly and positively affects the risk of transiting out of independent living; the effect being considerably greater once we control for unobserved heterogeneity. Estimates for duration dependence (presented in Table 6) also increase in magnitude once unobserved heterogeneity has been accounted for. These results suggest that duration dependence is negative across all destination states, i.e., individuals are less likely to transit out of independent living as the length of stay increases. Negative duration dependence may be due to an increased emotional attachment to this form of living arrangement. ${ }^{14}$ Furthermore, the fact that the magnitude of duration dependence is similar across all destination states suggests that duration is not a factor in determining whether a sick elderly individual transits into a nursing home or cohabitation.

Turning to the first part of Table 7, we find that being female increases the transition intensity associated with moving into a nursing home. This is not surprising given that women often outlive their spouse. Furthermore, it is likely that males are less able to care for their ailing wives than are women able to care for their ailing husbands (because of caregiving capital accumulation). Mothers also have a greater transition intensity associated with moving from an independent living arrangement to cohabitation. This result may reflect the relatively greater ability of mothers at providing 'home-making' services to the family unit such as caring for grandchildren.

Estimates also suggest that having more children increases the transition intensity associated with cohabitation. This is likely because: (i) parents with many children have a greater probability of finding a child who is able/willing to take care of and move-in with them; and/or (ii) larger

\footnotetext{
${ }^{14}$ For the purpose of estimation, we assume individuals become at risk of transiting into different living arrangements at 50 years of age. In fact, the first transition observed in our data set occurs at 51 years old.
} 
families are better able to share caregiving responsibilities by reducing the burden imposed on each caregiver. Furthermore, being married increases the transition intensity associated with moving from an independent living arrangement into a nursing home. Although this may seem surprising at first, it is important to note that this does not imply that individuals are more likely to end up in a nursing home if they are married given that married individuals are much less likely to transit into a nursing home if they are cohabiting. Thus, even if the probability of being in nursing home is negatively correlated with being married, it does not necessarily imply that married individuals are less at risk of transiting from an independent living arrangement into a nursing home.

Examining the coefficients for health indicators, we notice, as expected, that having difficulties with thinking, concentrating and memory or having experienced a stroke increases the transition intensity associated with a move from an independent living arrangement into a nursing home. Also, having difficulties hearing or suffering from angina decreases the same transition intensity. Home ownership, however, reduces this transition intensity (again, consistent with prior studies). This last result may capture several effects including: (i) an income effect, (ii) an inherent ability to take care of oneself, and/or (iii) an attachment to the current place of residence.

\subsection{Transitions out of Cohabitation}

With respect to elderly parents in need of care who are currently in cohabitation, we again find positive age duration, i.e., as individuals get older they are more likely to transit out of a cohabiting stay (see Table 5$)^{15}$. However, results from Table 6 suggest a rather different dynamic for transitions out of cohabitation than for transitions out of independent living. In fact, our results suggest that individuals are much less likely to return to independent living as the length of their cohabiting stay increases (while more likely to transit to nursing home or death). This result suggests that independent living is a very unlikely exit route for individuals who cohabit, especially as time goes by. This negative duration dependence may reflect a parent's growing dependency on informal

\footnotetext{
${ }^{15}$ The age duration effect is again much larger once we control for unobserved heterogeneity.
} 
family care or the increased fixed costs associated with returning to independent living (for example, as time goes by, it is more likely that the parent's home and other personal items will have been sold).

We also find in Table 7 that sick elderly mothers who cohabit (relative to sick elderly fathers who cohabit) are less at risk of transiting into nursing-home care as well as less at risk of dying (the transition intensity from cohabitation into independent living is not statistically different for men and women). Thus, estimates indicate that durations in shared living arrangements (cohabitation) are likely to be longer for women than they are for men. Part of the reason that cohabiting stays may be more stable for mothers than for fathers may be their ability in providing home-making services such as caring for grandchildren.

Results also indicate that having more children decreases the cohabitation-into-independentliving transition intensity. This result likely reflects the ability of larger families to care for their sick elderly parents in a shared living arrangement. Being married appears to reduce the transition intensity from cohabitation into nursing home. Results also indicate that suffering from heart or kidney disease or having problems seeing decreases the transition intensity associated with moving from cohabitation into a nursing home.

The negative duration dependence associated with transiting back into independent living from a cohabiting spell suggests the need to target policies. By encouraging, for example, individuals to remain in shared living arrangements (i.e., cohabitation), especially during the early periods, policies may ultimately serve to delay and reduce institutionalization.

\subsection{Transitions out of Nursing Homes}

Results also indicate that elderly parents in need of care are more likely to transit out of nursing home (for all states) as they grow older $\left(\gamma_{1}^{n h}=0.13\right.$ in Table 5). In stark contrast to transitions out of cohabitation, transitions out of nursing homes exhibit negative duration dependence for both transitions to independent living and cohabitation. Moreover, duration dependence for re-entry into 
independent living is also greater for individuals in nursing homes relative to cohabitation. These two results are consistent with financial and psychic costs associated with re-entry into independent living or cohabitation; costs which are likely to increase as time spent in a nursing home goes by.

It is worth contrasting duration-dependence coefficients (provided in Table 6) for transitions from nursing home to cohabitation (which are significantly negative in both specification) to those for transitions from cohabitation to nursing homes (which are significantly different from zero). These results underline the role of cohabitation as an important transitory living arrangement between independence and nursing-home care

Table 7 show that being married increases the likelihood of transiting from a nursing home care back into independent living. Furthermore, elderly individuals are less likely to return to independent living but more likely to transit into cohabitation, as the number of children increases. These results again underscore the importance of informal caregivers in avoiding nursing home stays.

Turning to health indicators, we find that having problems thinking, concentrating and with memory increases the transition intensity associated with moving out of a nursing home into an independent living arrangement. Furthermore, having problems seeing decreases the transition intensity associated with moving from a nursing home into cohabitation.

The effect of duration dependence is particularly important when formulating policies which seek to reduce institutionalization. As noted above, individuals are much less likely to ever transit out of a nursing home (either towards independent living or cohabitation) as the length of their nursinghome stay increases. Thus, policies which seek to encourage the re-entry of institutionalized elderly individuals into the community would appear to be more effective if they were targeted towards individuals at the early stages of their institutionalization. 


\section{Conclusion}

In this paper, we examine the living-arrangement dynamics of elderly individuals in need of care in a dynamic setting. Because elderly individuals often experience more than one type of living arrangements and that current living arrangements (as well as their lengths) likely influence future ones, we estimate a model which allows for such dynamic features. More specifically, we estimate a simultaneous random-effects competing-risks model which also controls for unobserved heterogeneity.

By using the full living arrangement history of elderly parents in need of care, we find that state, age and duration dependence are important. For example, we find that the likelihood that an individual transits into a nursing home is dependent on whether an individual is currently in a shared living arrangement (cohabitation) or in independent living as well as the length of time spent in either of these living arrangements. Furthermore, we find that cohabitation may serve

as an important barrier to ever transiting into a nursing home. Our results also indicate that cohabiting with a child may be a more effective substitute for nursing home care for women than it is for men (i.e., the risk of transiting from cohabitation to nursing home is smaller for mothers than it is for fathers).

Overall, our approach and results present a more complex picture of the living-arrangement decisions of sick elderly individuals than previous work based primarily on cross-sectional analysis. Furthermore, applying the same methodology to longitudinal data on aging would be interesting once these panels contain enough years to build the full living arrangement histories. Although we focus on sick elderly individuals with children (an important sub-population from a policy perspective), more complete data would allow us to broaden our analysis to the general elderly population. 


\section{References}

[1] Börsch-Supan, Axel, Laurence J. Kotlikoff, and John N. Morris (1991) 'The Dynamics of Living Arrangements of the Elderly,' in The Economics of Care of the Elderly, Pacolet, J. and C. Wilderom (eds.), 114-35.

[2] Börsch-Supan, Axel, Jagadesh Gokhale, Laurence J. Kotlikoff and John Morris (1992) 'The Provision of Time to the Elderly by Their Children,' in Topics in the Economics of Aging, David A. Wise (ed.), a NBER Project Report Series, Chicago: University of Chicago Press, $109-31$.

[3] Branch, L.G. and A.M. Jett (1982) 'A Prospective Study of Long-Term Care Institutionalization among the Aged,' American Journal of Public Health 72, 1373-79.

[4] Cohen, M.A., E.J. Tell and S.S. Wallack (1986) 'The Lifetime Risks and Costs of Nursing Home Use Among the Elderly,' Medical Care 24, 1161-72.

[5] Crowder, M. (2001) Classical Competing Risks, Chapman \& Hall/CRC.

[6] Dex, S. (1991) 'The reliability of recall data: a literature review,' Occasional Papers of ESRC Research on micro-social change, No. 6, University of Essex, Colchester.

[7] Dolton, Peter and Wilbert van der Klaauw (1999) 'The Turnover of Teachers: A Competing Risks Explanation,' Review of Economics and Statistics 81, 543-50.

[8] Engers, Maxim and Steven Stern (2002) 'Long-Term Care and Family Bargaining,' International Economics Review 43, 73-114.

[9] Garber, Alan M. and Thomas MaCurdy (1990) 'Predicting Nursing Home Utilization Among the High-Risk Elderly,' in Issues in the Economics of Aging. David A. Wise (ed.), Chicago: University of Chicago Press. 
[10] Greenberg, J.N. and A. Ginn (1979) 'A Multivariate Analysis of the Predictors of Long-Term Care Placement,' Home Health Care Services Quarterly 1, 75-99.

[11] Heiss, Florian, Michael Hurd and Axel Börsch-Supan (2003) 'Healthy, Wealthy, and Knowing Where to Live: Trajectories of Health, Wealth and Living Arrangements Among the Oldest Old,' NBER Working Paper No. 9897.

[12] Hidemann, Bridget and Steven Stern (1999) 'Strategic Play Among Family Members when Making Long-Term Care Decisions,' Journal of Economic Behavior and Organization 40, 2957.

[13] Kotlikoff, Laurence J. and John N. Morris (1990) 'Why Don't the Elderly Live with Their Children? A New Look,' in Issues in the Economics of Aging. David A. Wise (ed.), Chicago: University of Chicago Press.

[14] Lancaster, Tony (1990) The Econometric Analysis of Transition Data (Econometric Society Monographs No. 17). Cambridge UK: Cambridge University Press.

[15] Mealli, Fabrizia and Stephen Pudney (1996) 'Occupational Pensions and Job Mobility in Britain: Estimation of a Random-Effects Competing Risks Model', Journal of Applied Econometrics, 11, 293-320.

[16] Pezzin, Liliana E. and Barbara Steinberg Schone (1999) 'Intergenerational Household Formation, Female Labor Supply and Informal Caregiving: A Bargaining Approach,' Journal of Human Resources 34, 475-503.

[17] Stern, Steven (1996) 'Estimating Family Long-Term Care Decisions in the Presence of Endogenous Child Characteristics,' The Journal of Human Resources 30, 551-80.

[18] Stoller, Eleanor Palo (1983) 'Parental Caregiving by Adult Children,' Journal of Marriage and the Family November, 851-58. 
[19] White-Means, S.I. (1992) 'Allocation of Labor to Informal Home Health Production: Health Care for Frail Elderly, if Time Permits,' The Journal of Consumer Affairs 26, 69-89. 
Table 1: Fathers

\begin{tabular}{|c|c|c|c|c|c|}
\hline Living Arrangement & & Per cent & Min & Max & Average \\
\hline 1) Hospital Stay $\dagger$ & & $10.9 \%$ & & & \\
\hline \multirow{6}{*}{ 2) Nursing Home } & Censored & $6.4 \%$ (of $10.9 \%)$ & 210 & 300 & 240 \\
\hline & Died There & $93.6 \%$ (of $10.9 \%$ ) & $0 \ddagger$ & 2040 & 491.6 \\
\hline & & $24.6 \%$ & & & \\
\hline & Censored & $28,3 \%$ (of $24.6 \%$ ) & 30 & 510 & 250.3 \\
\hline & Died There & $55.7 \%$ (of $24.6 \%$ ) & 0 & 2790 & 897.8 \\
\hline & Transited & $13 \%$ (of $26.2 \%$ ) & 9 & 1825 & 268.5 \\
\hline \multirow[t]{4}{*}{ 3) Cohabitation } & & $22.3 \%$ & & & \\
\hline & Censored & $28.1 \%$ (of $22.3 \%$ ) & 30 & 450 & 236.7 \\
\hline & Died There & $47.9 \%$ (of $22.3 \%$ ) & 390 & 2460 & 761.9 \\
\hline & Transited & $24 \%$ (of $22.3 \%$ ) & 7 & 2555 & 394.8 \\
\hline \multirow[t]{4}{*}{ 4) Independent } & & $42 \%$ & & & \\
\hline & Censored & $28.2 \%$ (of $42 \%$ ) & 30 & 750 & 235 \\
\hline & Died There & $60.8 \%$ (of $42 \%)$ & 0 & 4470 & 973.1 \\
\hline & Transited & $11 \%$ (of $42 \%$ ) & 14 & 2555 & 402.9 \\
\hline
\end{tabular}

$\dagger$ Hospital Stays are coded as a living arrangement exclusively for

those individuals who entered a hospital and died there, or, entered a hospital and were still there (i.e., censored) in 1991.

$\ddagger$ Zeroes indicate death in the same month.

Table 2: Mothers

\begin{tabular}{|c|c|c|c|c|c|}
\hline Living Arrangement & & Per cent & Min & Max & Average \\
\hline 1) Hospital Stay $\dagger$ & & $6.3 \%$ & & & \\
\hline \multirow{6}{*}{ 2) Nursing Home } & Censored & $8.3 \%$ (of $6.3 \%)$ & 120 & 200 & 200 \\
\hline & Died There & $91.7 \%$ (of $6.3 \%$ ) & 360 & 3060 & 663.8 \\
\hline & & $31.3 \%$ & & & \\
\hline & Censored & $31.5 \%$ (of $31.3 \%$ ) & 60 & 660 & 281.6 \\
\hline & Died There & $58.2 \%$ (of $31.3 \%$ ) & $0 \ddagger$ & 9090 & 1265.2 \\
\hline & Transited & $10.3 \%$ (of $31.3 \%$ ) & 2 & 730 & 144.6 \\
\hline \multirow[t]{4}{*}{ 3) Cohabitation } & & $37.1 \%$ & & & \\
\hline & Censored & $39.9 \%$ (of $37.1 \%$ ) & 30 & 630 & 262 \\
\hline & Died There & $40.3 \%$ (of $37.1 \%$ ) & 360 & 10380 & 1414.1 \\
\hline & Transited & $20.4 \%$ of $(37.1 \%)$ & 3 & 5475 & 1012.8 \\
\hline \multirow[t]{4}{*}{ 4) Independent } & & $24.4 \%$ & & & \\
\hline & Censored & $38.1 \%$ (of $24.4 \%$ ) & 30 & 960 & 274 \\
\hline & Died There & $37.4 \%$ (of $24.4 \%$ ) & 390 & 9480 & 1645 \\
\hline & Transited & $24.5 \%$ (of $24.4 \%$ ) & 21 & 5475 & 573.1 \\
\hline
\end{tabular}

$\dagger$ Hospital Stays are coded as a living arrangement exclusively for those individuals who entered a hospital and died there, or, entered a hospital and were still there (i.e., censored) in 1991.

$\ddagger$ Zeroes indicate death in the same month. 
Table 3: Variables Description

\begin{tabular}{|c|c|}
\hline \multicolumn{2}{|c|}{ "Demographic information } \\
\hline Mother & Dummy variable: 1 for mothers \\
\hline NumChild & Number of child \\
\hline Rural & Dummy variable: 1 if married \\
\hline \multicolumn{2}{|l|}{ Wealth } \\
\hline Own Home & Dummy variable: 1 if owns home \\
\hline \multicolumn{2}{|c|}{ Health: difficulties with Activities of Daily Living (ADL) } \\
\hline Eating & Dummy variable: 1 if difficulties with eating alone \\
\hline Walking & Dummy variable: 1 if difficulties with walking \\
\hline Hearing & Dummy variable: 1 if difficulties with hearing \\
\hline Seeing & Dummy variable: 1 if difficulties with seeing \\
\hline Think & Dummy variable: 1 if difficulties with thinking \\
\hline \multicolumn{2}{|c|}{ Health: illnesses } \\
\hline Heart & Dummy variable: 1 if heart problems \\
\hline Angina & Dummy variable: 1 if angina problems \\
\hline Kidney & Dummy variable: 1 if kidney problems \\
\hline Contbow & Dummy variable: 1 if problems controlling bowels \\
\hline Stroke & Dummy variable: 1 if individual had a stroke \\
\hline
\end{tabular}


Table 4: Summary statistics at times of transition

\begin{tabular}{|c|c|c|c|c|c|c|c|c|}
\hline & \multicolumn{2}{|c|}{ From: } & \multicolumn{6}{|c|}{ Transition to: } \\
\hline & \multicolumn{2}{|c|}{ Independent } & \multicolumn{2}{|c|}{ Nursing home } & \multicolumn{2}{|c|}{ Cohabitation } & \multicolumn{2}{|c|}{ Death } \\
\hline & \multicolumn{2}{|c|}{$\mathrm{N}=932$} & \multicolumn{2}{|c|}{$\mathrm{N}=291$} & \multicolumn{2}{|c|}{$\mathrm{N}=283$} & \multicolumn{2}{|c|}{$\mathrm{N}=240$} \\
\hline & Mean & Std Dev. & Mean & Std Dev. & Mean & Std Dev. & Mean & Std Dev. \\
\hline \multicolumn{9}{|c|}{ Demographic information } \\
\hline Mother & 0.55 & 0.50 & 0.63 & 0.48 & 0.67 & 0.47 & 0.34 & 0.48 \\
\hline NumChild & 4.15 & 2.71 & 3.69 & 2.25 & 4.69 & 2.88 & 4.06 & 2.81 \\
\hline Rural & 0.34 & 0.48 & 0.35 & 0.48 & 0.34 & 0.47 & 0.32 & 0.47 \\
\hline Age & 78.97 & 7.81 & 80.94 & 7.53 & 77.81 & 8.14 & 79.30 & 7.15 \\
\hline $\begin{array}{l}\text { Married } \\
\text { Wealth }\end{array}$ & 0.45 & 0.50 & 0.34 & 0.47 & 0.25 & 0.43 & 0.73 & 0.45 \\
\hline Own Home & 0.64 & 0.48 & 0.53 & 0.50 & 0.60 & 0.49 & 0.75 & 0.43 \\
\hline \multicolumn{9}{|c|}{ Health: difficulties with Activities of Daily Living (ADL) } \\
\hline Eating & 0.29 & 0.45 & 0.31 & 0.46 & 0.27 & 0.44 & 0.34 & 0.48 \\
\hline Walking & 0.45 & 0.50 & 0.50 & 0.50 & 0.39 & 0.49 & 0.51 & 0.50 \\
\hline Hearing & 0.33 & 0.47 & 0.34 & 0.47 & 0.27 & 0.44 & 0.35 & 0.48 \\
\hline Seeing & 0.30 & 0.46 & 0.27 & 0.44 & 0.33 & 0.47 & 0.28 & 0.45 \\
\hline Think & 0.46 & 0.50 & 0.56 & 0.50 & 0.43 & 0.50 & 0.34 & 0.48 \\
\hline \multicolumn{9}{|c|}{ Health: illnesses } \\
\hline Heart & 0.38 & 0.49 & 0.34 & 0.47 & 0.35 & 0.48 & 0.47 & 0.50 \\
\hline Angina & 0.23 & 0.42 & 0.20 & 0.40 & 0.24 & 0.43 & 0.27 & 0.44 \\
\hline Kidney & 0.11 & 0.31 & 0.08 & 0.27 & 0.08 & 0.28 & 0.14 & 0.35 \\
\hline Contbow & 0.22 & 0.42 & 0.31 & 0.46 & 0.23 & 0.42 & 0.09 & 0.28 \\
\hline Stroke & 0.33 & 0.47 & 0.42 & 0.49 & 0.27 & 0.44 & 0.30 & 0.46 \\
\hline
\end{tabular}


Table 4: cont'd

\begin{tabular}{|c|c|c|c|c|c|c|c|c|}
\hline & \multicolumn{2}{|c|}{ From: } & \multicolumn{6}{|c|}{ Transition to: } \\
\hline & \multicolumn{2}{|c|}{ Cohabitation } & \multicolumn{2}{|c|}{ Independent } & \multicolumn{2}{|c|}{ Nursing home } & \multicolumn{2}{|c|}{ Death } \\
\hline & \multicolumn{2}{|c|}{$\mathrm{N}=300$} & \multicolumn{2}{|c|}{$\mathrm{N}=11$} & \multicolumn{2}{|c|}{$\mathrm{N}=44$} & \multicolumn{2}{|c|}{$\mathrm{N}=125$} \\
\hline & Mean & Std Dev. & Mean & Std Dev. & Mean & Std Dev. & Mean & Std Dev. \\
\hline \multicolumn{9}{|c|}{ Demographic information } \\
\hline Mother & 0.68 & 0.47 & 0.54 & 0.52 & 0.68 & 0.47 & 0.62 & 0.49 \\
\hline NumChild & 4.79 & 2.98 & 3.00 & 1.90 & 4.18 & 2.07 & 4.94 & 3.03 \\
\hline Rural & 0.34 & 0.47 & 0.18 & 0.40 & 0.32 & 0.47 & 0.34 & 0.47 \\
\hline Age & 79.76 & 8.33 & 77.92 & 6.68 & 80.34 & 8.83 & 82.34 & 7.66 \\
\hline $\begin{array}{l}\text { Married } \\
\text { Wealth }\end{array}$ & 0.22 & 0.42 & 0.18 & 0.40 & 0.09 & 0.29 & 0.30 & 0.46 \\
\hline Own Home & 0.60 & 0.49 & 0.54 & 0.52 & 0.45 & 0.50 & 0.64 & 0.48 \\
\hline \multicolumn{9}{|c|}{ Health: difficulties with Activities of Daily Living (ADL) } \\
\hline Eating & 0.26 & 0.44 & 0.27 & 0.47 & 0.23 & 0.42 & 0.40 & 0.49 \\
\hline Walking & 0.38 & 0.49 & 0.45 & 0.52 & 0.32 & 0.47 & 0.50 & 0.50 \\
\hline Hearing & 0.35 & 0.48 & 0.18 & 0.40 & 0.30 & 0.46 & 0.36 & 0.48 \\
\hline Seeing & 0.36 & 0.48 & 0.09 & 0.30 & 0.27 & 0.45 & 0.38 & 0.49 \\
\hline Think & 0.48 & 0.50 & 0.45 & 0.52 & 0.36 & 0.49 & 0.42 & 0.49 \\
\hline \multicolumn{9}{|c|}{ Health: illnesses } \\
\hline Heart & 0.40 & 0.50 & 0.27 & 0.47 & 0.27 & 0.45 & 0.50 & 0.50 \\
\hline Angina & 0.26 & 0.44 & 0.18 & 0.40 & 0.20 & 0.41 & 0.29 & 0.45 \\
\hline Kidney & 0.11 & 0.31 & 0.09 & 0.30 & 0.05 & 0.21 & 0.14 & 0.34 \\
\hline Contbow & 0.17 & 0.37 & 0.27 & 0.47 & 0.14 & 0.35 & 0.07 & 0.26 \\
\hline Stroke & 0.31 & 0.46 & 0.00 & 0.00 & 0.25 & 0.44 & 0.36 & 0.48 \\
\hline
\end{tabular}


Table 4: cont'd

\begin{tabular}{|c|c|c|c|c|c|c|c|c|}
\hline & \multicolumn{2}{|c|}{ From: } & \multicolumn{6}{|c|}{ Transition to: } \\
\hline & \multicolumn{2}{|c|}{ Nursing home } & \multicolumn{2}{|c|}{ Cohabitation } & \multicolumn{2}{|c|}{ Independent } & \multicolumn{2}{|c|}{ Death } \\
\hline & \multicolumn{2}{|c|}{$\mathrm{N}=326$} & \multicolumn{2}{|c|}{$\mathrm{N}=12$} & \multicolumn{2}{|c|}{$\mathrm{N}=15$} & \multicolumn{2}{|c|}{$\mathrm{N}=189$} \\
\hline & Mean & Std Dev. & Mean & Std Dev. & Mean & Std Dev. & Mean & Std Dev. \\
\hline \multicolumn{9}{|c|}{ Demographic information } \\
\hline Mother & 0.64 & 0.48 & 0.67 & 0.49 & 0.47 & 0.52 & 0.62 & 0.49 \\
\hline NumChild & 3.75 & 2.24 & 5.58 & 4.01 & 2.87 & 1.73 & 3.76 & 2.11 \\
\hline Rural & 0.34 & 0.47 & 0.50 & 0.52 & 0.20 & 0.41 & 0.33 & 0.47 \\
\hline Age & 82.86 & 7.89 & 80.72 & 6.77 & 77.57 & 8.26 & 84.22 & 7.68 \\
\hline $\begin{array}{l}\text { Married } \\
\text { Wealth }\end{array}$ & 0.31 & 0.46 & 0.08 & 0.29 & 0.53 & 0.52 & 0.33 & 0.47 \\
\hline Own Home & 0.51 & 0.50 & 0.42 & 0.51 & 0.67 & 0.49 & 0.54 & 0.50 \\
\hline \multicolumn{9}{|c|}{ Health: difficulties with Activities of Daily Living (ADL) } \\
\hline Eating & 0.31 & 0.46 & 0.25 & 0.45 & 0.27 & 0.46 & 0.30 & 0.46 \\
\hline Walking & 0.49 & 0.50 & 0.42 & 0.51 & 0.47 & 0.52 & 0.47 & 0.50 \\
\hline Hearing & 0.37 & 0.48 & 0.58 & 0.51 & 0.33 & 0.49 & 0.39 & 0.49 \\
\hline Seeing & 0.31 & 0.46 & 0.08 & 0.29 & 0.47 & 0.52 & 0.37 & 0.48 \\
\hline Think & 0.50 & 0.50 & 0.42 & 0.51 & 0.73 & 0.46 & 0.43 & 0.50 \\
\hline \multicolumn{9}{|c|}{ Health: illnesses } \\
\hline Heart & 0.40 & 0.49 & 0.33 & 0.49 & 0.60 & 0.51 & 0.46 & 0.50 \\
\hline Angina & 0.20 & 0.40 & 0.42 & 0.51 & 0.40 & 0.51 & 0.20 & 0.40 \\
\hline Kidney & 0.11 & 0.31 & 0.08 & 0.29 & 0.07 & 0.26 & 0.13 & 0.33 \\
\hline Contbow & 0.17 & 0.38 & 0.17 & 0.39 & 0.33 & 0.48 & 0.06 & 0.24 \\
\hline Stroke & 0.46 & 0.50 & 0.42 & 0.51 & 0.53 & 0.52 & 0.49 & 0.50 \\
\hline
\end{tabular}

Table 5: Living Arrangment Dynamics I

\begin{tabular}{lcc}
\hline \hline & \multicolumn{2}{c}{ Age dependence $\left(\gamma_{1}^{b}\right)-$ All States } \\
\cline { 2 - 3 } Independent & Base & Mixed \\
\cline { 2 - 3 } & $0.22^{* *}$ & $0.34^{* *}$ \\
Cohabitation & $0.01)$ & $(0.01)$ \\
& $0.03^{* *}$ & $0.12^{* *}$ \\
Nursing Home & $(0.01)$ & $(0.02)$ \\
& $0.03^{* *}$ & $0.13^{* *}$ \\
& $(0.01)$ & $(0.02)$ \\
\hline \hline
\end{tabular}

NOTE: Standard Errors in Parentheses

** indicates statistical significance at the $5 \%$ level. 
Table 6: Living Arrangment Dynamics II

\begin{tabular}{|c|c|c|c|c|c|c|c|c|}
\hline & \multicolumn{8}{|c|}{ "Duration dependence $\left(\gamma_{0}^{b e}\right)$} \\
\hline & \multicolumn{2}{|c|}{ Independent } & \multicolumn{2}{|c|}{ Cohabitation } & \multicolumn{2}{|c|}{ Nursing Home } & \multicolumn{2}{|c|}{ Death } \\
\hline & Base & Mixed & Base & Mixed & Base & Mixed & $\overline{\text { Base }}$ & Mixed \\
\hline Independent & & & $\begin{array}{c}-0.08^{* *} \\
(0.00)\end{array}$ & $\begin{array}{c}-0.13^{* *} \\
(0.01)\end{array}$ & $\begin{array}{c}-0.10^{* *} \\
(0.01)\end{array}$ & $\begin{array}{c}-0.11^{* *} \\
(0.01)\end{array}$ & $\begin{array}{c}-0.10^{* *} \\
(0.01)\end{array}$ & $\begin{array}{c}-0.14^{* *} \\
(0.01)\end{array}$ \\
\hline Cohabitation & $\begin{array}{c}-2.71^{* *} \\
(1.08)\end{array}$ & $\begin{array}{c}-2.63^{* *} \\
(1.07)\end{array}$ & & & $\begin{array}{c}0.03 \\
(0.05)\end{array}$ & $\begin{array}{c}0.06 \\
(0.06)\end{array}$ & $\begin{array}{c}0.02 \\
(0.03)\end{array}$ & $\begin{array}{l}0.05^{*} \\
(0.03)\end{array}$ \\
\hline Nursing Home & $\begin{array}{c}-3.66^{* *} \\
(1.11)\end{array}$ & $\begin{array}{c}-3.57^{* *} \\
(1.09)\end{array}$ & $\begin{array}{c}-0.65^{* *} \\
(0.36)\end{array}$ & $\begin{array}{c}-0.58^{*} \\
(0.36)\end{array}$ & & & $\begin{array}{l}-0.00 \\
(0.02)\end{array}$ & $\begin{array}{c}0.02 \\
(0.03)\end{array}$ \\
\hline
\end{tabular}

NOTE: Standard Errors in Parentheses

** $(*)$ indicates statistical significance at the $5 \%(10 \%)$ level. 
Table 7: Parameter Estimates - Markov Model

\begin{tabular}{|c|c|c|c|c|c|c|}
\hline \multirow{3}{*}{$\begin{array}{l}\text { State of origin: } \\
\text { Independent }\end{array}$} & \multicolumn{6}{|c|}{ Destination State } \\
\hline & \multicolumn{2}{|c|}{ Nursing Home } & \multicolumn{2}{|c|}{ Cohabitation. } & \multicolumn{2}{|c|}{ Death } \\
\hline & Base & Mixed & Base & Mixed & Base & Mixed \\
\hline \multicolumn{7}{|c|}{ Wealth and Demographics } \\
\hline Constant & $\begin{array}{l}-22.40^{* *} \\
(0.66)\end{array}$ & $\begin{array}{l}-32.49^{* *} \\
(1.42)\end{array}$ & $\begin{array}{l}-20.38^{* *} \\
(0.57)\end{array}$ & $\begin{array}{l}-29.90^{* *} \\
(1.32)\end{array}$ & $\begin{array}{l}-20.08^{* *} \\
(0.58)\end{array}$ & $\begin{array}{l}-29.44^{* *} \\
(1.33)\end{array}$ \\
\hline Mother & $\begin{array}{l}0.35^{* *} \\
(0.14)\end{array}$ & $\begin{array}{l}0.38^{* *} \\
(0.16)\end{array}$ & $\begin{array}{l}0.31^{* *} \\
(0.14)\end{array}$ & $\begin{array}{l}0.31^{*} \\
(0.17)\end{array}$ & $\begin{array}{l}-0.29^{*} \\
(0.16)\end{array}$ & $\begin{array}{l}-0.30^{*} \\
(0.15)\end{array}$ \\
\hline NumChild & $\begin{array}{l}-0.04 \\
(0.03)\end{array}$ & $\begin{array}{l}-0.04 \\
(0.03)\end{array}$ & $\begin{array}{l}0.10^{* *} \\
(0.02)\end{array}$ & $\begin{array}{l}0.11^{* *} \\
(0.03)\end{array}$ & $\begin{array}{l}0.01 \\
(0.02)\end{array}$ & $\begin{array}{l}0.03 \\
(0.03)\end{array}$ \\
\hline Rural & $\begin{array}{l}0.33^{* *} \\
(0.13)\end{array}$ & $\begin{array}{l}0.42^{* *} \\
(0.16)\end{array}$ & $\begin{array}{l}0.06 \\
(0.13)\end{array}$ & $\begin{array}{l}0.17 \\
(0.17)\end{array}$ & $\begin{array}{l}-0.15 \\
(0.14)\end{array}$ & $\begin{array}{l}-0.14 \\
(0.18)\end{array}$ \\
\hline Married & $\begin{array}{l}0.68^{* *} \\
(0.15)\end{array}$ & $\begin{array}{l}0.74^{* *} \\
(0.18)\end{array}$ & $\begin{array}{l}-0.11 \\
(0.16)\end{array}$ & $\begin{array}{l}-0.05 \\
(0.17)\end{array}$ & $\begin{array}{l}1.73^{* *} \\
(0.18)\end{array}$ & $\begin{array}{l}1.85^{* *} \\
(0.19)\end{array}$ \\
\hline Own Home & $\begin{array}{l}-0.32^{* *} \\
(0.13)\end{array}$ & $\begin{array}{l}-0.51^{* *} \\
(0.16)\end{array}$ & $\begin{array}{l}0.07 \\
(0.13)\end{array}$ & $\begin{array}{l}-0.09 \\
(0.16)\end{array}$ & $\begin{array}{l}0.17 \\
(0.16)\end{array}$ & $\begin{array}{l}-0.01 \\
(0.19)\end{array}$ \\
\hline Health & & & & & & \\
\hline Eating & $\begin{array}{l}-0.15 \\
(0.15)\end{array}$ & $\begin{array}{l}-0.10 \\
(0.19)\end{array}$ & $\begin{array}{l}0.07 \\
(0.17)\end{array}$ & $\begin{array}{l}0.11 \\
(0.21)\end{array}$ & $\begin{array}{l}0.01 \\
(0.17)\end{array}$ & $\begin{array}{l}0.12 \\
(0.21)\end{array}$ \\
\hline Walking & $\begin{array}{l}0.17 \\
(0.14)\end{array}$ & $\begin{array}{l}0.28 \\
(0.18)\end{array}$ & $\begin{array}{l}-0.31^{* *} \\
(0.16)\end{array}$ & $\begin{array}{l}-0.15 \\
(0.19)\end{array}$ & $\begin{array}{l}0.34^{* *} \\
(0.16)\end{array}$ & $\begin{array}{l}0.42^{* *} \\
(0.19)\end{array}$ \\
\hline Hearing & $\begin{array}{l}-0.54^{* *} \\
(0.13)\end{array}$ & $\begin{array}{l}-0.84^{* *} \\
(0.16)\end{array}$ & $\begin{array}{l}-1.01^{* *} \\
(0.15)\end{array}$ & $\begin{array}{l}-1.25^{* *} \\
(0.18)\end{array}$ & $\begin{array}{l}-0.42^{* *} \\
(0.15)\end{array}$ & $\begin{array}{l}-0.65^{* *} \\
(0.17)\end{array}$ \\
\hline Seeing & $\begin{array}{l}-0.23 \\
(0.14)\end{array}$ & $\begin{array}{c}-0.29^{*} \\
(0.16)\end{array}$ & $\begin{array}{l}0.17 \\
(0.14)\end{array}$ & $\begin{array}{l}0.12 \\
(0.16)\end{array}$ & $\begin{array}{l}-0.28^{*} \\
(0.15)\end{array}$ & $\begin{array}{l}-0.28 \\
(0.18)\end{array}$ \\
\hline Think & $\begin{array}{l}0.39^{* *} \\
(0.13)\end{array}$ & $\begin{array}{l}0.49^{* *} \\
(0.14)\end{array}$ & $\begin{array}{l}-0.18 \\
(0.13)\end{array}$ & $\begin{array}{l}-0.08 \\
(0.14)\end{array}$ & $\begin{array}{l}-0.17 \\
(0.14)\end{array}$ & $\begin{array}{l}-0.14 \\
(0.15)\end{array}$ \\
\hline Heart & $\begin{array}{l}-0.03 \\
(0.15)\end{array}$ & $\begin{array}{l}-0.12 \\
(0.17)\end{array}$ & $\begin{array}{l}-0.12 \\
(0.16)\end{array}$ & $\begin{array}{l}-0.16 \\
(0.18)\end{array}$ & $\begin{array}{l}0.34^{* *} \\
(0.15)\end{array}$ & $\begin{array}{l}0.43^{* *} \\
(0.17)\end{array}$ \\
\hline Angina & $\begin{array}{l}-0.31^{*} \\
(0.18)\end{array}$ & $\begin{array}{l}-0.39^{*} \\
(0.20)\end{array}$ & $\begin{array}{l}0.08 \\
(0.18)\end{array}$ & $\begin{array}{l}-0.01 \\
(0.20)\end{array}$ & $\begin{array}{l}0.17 \\
(0.18)\end{array}$ & $\begin{array}{l}0.01 \\
(0.21)\end{array}$ \\
\hline Kidney & $\begin{array}{l}0.25 \\
(0.22)\end{array}$ & $\begin{array}{l}0.47 \\
(0.31)\end{array}$ & $\begin{array}{l}0.05 \\
(0.22)\end{array}$ & $\begin{array}{l}0.32 \\
(0.31)\end{array}$ & $\begin{array}{l}0.72^{* *} \\
(0.19)\end{array}$ & $\begin{array}{l}1.08^{* *} \\
(0.32)\end{array}$ \\
\hline Contbow & $\begin{array}{l}0.05 \\
(0.14)\end{array}$ & $\begin{array}{l}-0.03 \\
(0.16)\end{array}$ & $\begin{array}{l}-0.01 \\
(0.16)\end{array}$ & $\begin{array}{l}-0.11 \\
(0.17)\end{array}$ & $\begin{array}{l}-1.36^{* *} \\
(0.23)\end{array}$ & $\begin{array}{l}-1.46^{* *} \\
(0.25)\end{array}$ \\
\hline Stroke & $\begin{array}{l}0.49^{* *} \\
(0.12)\end{array}$ & $\begin{array}{l}0.61^{* *} \\
(0.14)\end{array}$ & $\begin{array}{l}-0.09 \\
(0.14)\end{array}$ & $\begin{array}{l}-0.02 \\
(0.15)\end{array}$ & $\begin{array}{l}-0.14 \\
(0.14) \\
\end{array}$ & $\begin{array}{l}-0.17 \\
(0.17)\end{array}$ \\
\hline
\end{tabular}

NOTE: Standard Errors in Parentheses

** $(*)$ indicates statistical significance at the 5\% (10\%) level. 
Table 7: cont'd

\begin{tabular}{|c|c|c|c|c|c|c|}
\hline \multirow{3}{*}{$\begin{array}{l}\text { State of origin: } \\
\text { Cohabitation }\end{array}$} & \multicolumn{6}{|c|}{ Destination State } \\
\hline & \multicolumn{2}{|c|}{ Nursing Home } & \multicolumn{2}{|c|}{ Independent } & \multicolumn{2}{|c|}{ Death } \\
\hline & Base & Mixed & Base & Mixed & Base & Mixed \\
\hline \multicolumn{7}{|c|}{ Wealth and Demographics } \\
\hline \multirow[t]{2}{*}{ Constant } & $-2.81^{* *}$ & $-10.20^{* *}$ & $-2.28 * *$ & $-9.96 * *$ & $-3.65 * *$ & $-11.26^{* *}$ \\
\hline & $(0.90)$ & $(1.40)$ & $(1.24)$ & $(1.68)$ & $(0.84)$ & $(1.36)$ \\
\hline \multirow[t]{2}{*}{ Mother } & $-1.08^{* *}$ & $-1.00^{* *}$ & -0.90 & -0.75 & $-0.68^{* *}$ & $-0.50^{* *}$ \\
\hline & $(0.37)$ & $(0.41)$ & $(0.66)$ & $(0.67)$ & $(0.21)$ & $(0.26)$ \\
\hline \multirow[t]{2}{*}{ NumChild } & -0.07 & -0.06 & $-0.30^{*}$ & $-0.29^{*}$ & 0.00 & 0.03 \\
\hline & $(0.06)$ & $(0.06)$ & $(0.17)$ & $(0.17)$ & $(0.04)$ & $(0.04)$ \\
\hline \multirow[t]{2}{*}{ Rural } & 0.21 & 0.24 & -0.26 & -0.22 & $-0.38^{*}$ & $-0.49^{*}$ \\
\hline & $(0.36)$ & $(0.40)$ & $(0.86)$ & $(0.87)$ & $(0.21)$ & $(0.26)$ \\
\hline \multirow[t]{2}{*}{ Married } & $-1.31^{* *}$ & $-0.97^{*}$ & -0.13 & 0.07 & 0.16 & $0.55^{* *}$ \\
\hline & $(0.58)$ & $(0.59)$ & $(0.83)$ & $(0.84)$ & $(0.24)$ & $(0.28)$ \\
\hline \multirow{2}{*}{ Own Home } & -0.33 & $-0.71^{*}$ & -0.17 & -0.41 & 0.21 & -0.09 \\
\hline & $(0.35)$ & $(0.38)$ & $(0.67)$ & $(0.68)$ & $(0.21)$ & $(0.25)$ \\
\hline \multicolumn{7}{|l|}{ Health } \\
\hline \multirow[t]{2}{*}{ Eating } & -0.04 & 0.12 & -0.06 & 0.05 & 0.06 & 0.40 \\
\hline & $(0.55)$ & $(0.54)$ & $(0.93)$ & $(0.92)$ & $(0.29)$ & $(0.33)$ \\
\hline \multirow[t]{2}{*}{ Walking } & -0.20 & -0.05 & 0.24 & 0.36 & 0.19 & 0.38 \\
\hline & $(0.52)$ & $(0.51)$ & $(0.81)$ & $(0.80)$ & $(0.29)$ & $(0.32)$ \\
\hline \multirow{2}{*}{ Hearing } & -0.40 & $-0.76^{*}$ & -0.92 & -1.21 & 0.09 & -0.22 \\
\hline & $(0.38)$ & $(0.43)$ & $(0.87)$ & $(0.89)$ & $(0.22)$ & $(0.28)$ \\
\hline \multirow[t]{2}{*}{ Seeing } & $-0.63^{*}$ & -0.62 & -1.35 & -1.44 & -0.21 & -0.34 \\
\hline & $(0.39)$ & $(0.43)$ & (1.09) & $(1.12)$ & $(0.21)$ & $(0.26)$ \\
\hline \multirow[t]{2}{*}{ Think } & 0.14 & 0.10 & 0.18 & 0.31 & 0.13 & 0.11 \\
\hline & $(0.33)$ & $(0.36)$ & $(0.64)$ & $(0.66)$ & $(0.20)$ & $(0.24)$ \\
\hline \multirow[t]{2}{*}{ Heart } & $-1.08^{* *}$ & $-1.31^{* *}$ & -0.15 & -0.38 & 0.26 & 0.05 \\
\hline & $(0.52)$ & $(0.55)$ & $(0.93)$ & $(0.92)$ & $(0.24)$ & $(0.29)$ \\
\hline \multirow[t]{2}{*}{ Angina } & 0.37 & 0.26 & -0.05 & -0.12 & -0.23 & -0.38 \\
\hline & $(0.59)$ & $(0.61)$ & $(1.03)$ & $(1.02)$ & $(0.27)$ & $(0.31)$ \\
\hline \multirow[t]{2}{*}{ Kidney } & $-1.67^{* *}$ & $-1.43^{*}$ & 0.13 & 0.30 & 0.22 & $0.64^{*}$ \\
\hline & $(0.81)$ & $(0.86)$ & $(1.21)$ & $(1.26)$ & $(0.30)$ & $(0.38)$ \\
\hline \multirow[t]{2}{*}{ Contbow } & 0.37 & 0.25 & 1.04 & 0.93 & $-0.65^{*}$ & $-0.92^{* *}$ \\
\hline & $(0.51)$ & $(0.56)$ & $(0.77)$ & $(0.77)$ & $(0.38)$ & $(0.43)$ \\
\hline \multirow[t]{2}{*}{ Stroke } & -0.27 & -0.36 & $\dagger$ & $\dagger$ & 0.09 & -0.02 \\
\hline & $(0.40)$ & $(0.41)$ & $\dagger$ & $\dagger$ & $(0.22)$ & $(0.25)$ \\
\hline
\end{tabular}

NOTE: Standard Errors in Parentheses

** $(*)$ indicates statistical significance at the 5\% (10\%) level.

$\dagger$ no variation in explanatory variable 
Table 7: cont'd

\begin{tabular}{|c|c|c|c|c|c|c|}
\hline \multirow{3}{*}{$\begin{array}{l}\text { State of origin: } \\
\text { Nursing Home }\end{array}$} & \multicolumn{6}{|c|}{ Destination State } \\
\hline & \multicolumn{2}{|c|}{ Independent } & \multicolumn{2}{|c|}{ Cohabitation. } & \multicolumn{2}{|c|}{ Death } \\
\hline & Base & Mixed & Base & Mixed & Base & Mixed \\
\hline \multicolumn{7}{|c|}{ Wealth and Demographics } \\
\hline Constant & $\begin{array}{l}-4.30^{* *} \\
(1.32)\end{array}$ & $\begin{array}{l}-12.84^{* *} \\
(1.85)\end{array}$ & $\begin{array}{l}-6.87^{* *} \\
(1.43)\end{array}$ & $\begin{array}{l}-15.52^{* *} \\
(1.93)\end{array}$ & $\begin{array}{l}-3.84^{* *} \\
(0.84)\end{array}$ & $\begin{array}{l}-12.48^{\text {** }} \\
(1.52)\end{array}$ \\
\hline Mother & $\begin{array}{l}-0.79 \\
(0.57)\end{array}$ & $\begin{array}{l}-0.77 \\
(0.60)\end{array}$ & $\begin{array}{l}-0.10 \\
(0.69)\end{array}$ & $\begin{array}{l}-0.01 \\
(0.73)\end{array}$ & $\begin{array}{l}-0.45^{* *} \\
(0.18)\end{array}$ & $\begin{array}{l}-0.46^{* *} \\
(0.23)\end{array}$ \\
\hline NumChild & $\begin{array}{l}-0.32^{*} \\
(0.18)\end{array}$ & $\begin{array}{l}-0.34^{*} \\
(0.18)\end{array}$ & $\begin{array}{l}0.22^{*} \\
(0.12)\end{array}$ & $\begin{array}{l}0.25^{* *} \\
(0.12)\end{array}$ & $\begin{array}{l}-0.01 \\
(0.04)\end{array}$ & $\begin{array}{l}-0.00 \\
(0.05)\end{array}$ \\
\hline Rural & $\begin{array}{l}-0.66 \\
(0.68)\end{array}$ & $\begin{array}{l}-0.69 \\
(0.70)\end{array}$ & $\begin{array}{l}0.24 \\
(0.67)\end{array}$ & $\begin{array}{l}0.11 \\
(0.71)\end{array}$ & $\begin{array}{l}-0.10 \\
(0.17)\end{array}$ & $\begin{array}{l}-0.19 \\
(0.26)\end{array}$ \\
\hline Married & $\begin{array}{l}0.78 \\
(0.59)\end{array}$ & $\begin{array}{l}1.14^{*} \\
(0.61)\end{array}$ & $\begin{array}{l}-1.80 \\
(1.14)\end{array}$ & $\begin{array}{l}-1.60 \\
(1.16)\end{array}$ & $\begin{array}{l}-0.13 \\
(0.18)\end{array}$ & $\begin{array}{l}0.12 \\
(0.24)\end{array}$ \\
\hline Own Home & $\begin{array}{l}0.72 \\
(0.63)\end{array}$ & $\begin{array}{l}0.60 \\
(0.66)\end{array}$ & $\begin{array}{l}0.24 \\
(0.67)\end{array}$ & $\begin{array}{l}0.06 \\
(0.70)\end{array}$ & $\begin{array}{l}0.09 \\
(0.17)\end{array}$ & $\begin{array}{l}-0.02 \\
(0.22)\end{array}$ \\
\hline Health & & & & & & \\
\hline Eating & $\begin{array}{l}-0.34 \\
(0.75)\end{array}$ & $\begin{array}{l}-0.43 \\
(0.77)\end{array}$ & $\begin{array}{l}-0.11 \\
(0.81)\end{array}$ & $\begin{array}{l}-0.23 \\
(0.89)\end{array}$ & $\begin{array}{l}0.44^{* *} \\
(0.20)\end{array}$ & $\begin{array}{l}0.33 \\
(0.29)\end{array}$ \\
\hline Walking & $\begin{array}{l}-0.40 \\
(0.68)\end{array}$ & $\begin{array}{l}-0.17 \\
(0.70)\end{array}$ & $\begin{array}{l}0.41 \\
(0.78)\end{array}$ & $\begin{array}{l}0.71 \\
(0.82)\end{array}$ & $\begin{array}{l}-0.03 \\
(0.18)\end{array}$ & $\begin{array}{l}0.32 \\
(0.27)\end{array}$ \\
\hline Hearing & $\begin{array}{l}-0.46 \\
(0.61)\end{array}$ & $\begin{array}{l}-0.83 \\
(0.62)\end{array}$ & $\begin{array}{l}1.04 \\
(0.71)\end{array}$ & $\begin{array}{l}0.65 \\
(0.72)\end{array}$ & $\begin{array}{l}-0.21 \\
(0.17)\end{array}$ & $\begin{array}{l}-0.41^{*} \\
(0.24)\end{array}$ \\
\hline Seeing & $\begin{array}{l}0.48 \\
(0.56)\end{array}$ & $\begin{array}{l}0.32 \\
(0.57)\end{array}$ & $\begin{array}{l}-2.23^{* *} \\
(1.16)\end{array}$ & $\begin{array}{l}-2.38^{* *} \\
(1.17)\end{array}$ & $\begin{array}{l}-0.14 \\
(0.17)\end{array}$ & $\begin{array}{l}-0.35 \\
(0.25)\end{array}$ \\
\hline Think & $\begin{array}{l}1.04^{*} \\
(0.62)\end{array}$ & $\begin{array}{l}1.12^{*} \\
(0.64)\end{array}$ & $\begin{array}{l}-0.50 \\
(0.71)\end{array}$ & $\begin{array}{l}-0.47 \\
(0.73)\end{array}$ & $\begin{array}{l}-0.06 \\
(0.16)\end{array}$ & $\begin{array}{l}-0.10 \\
(0.20)\end{array}$ \\
\hline Heart & $\begin{array}{l}0.41 \\
(0.69)\end{array}$ & $\begin{array}{l}0.45 \\
(0.71)\end{array}$ & $\begin{array}{l}-0.77 \\
(0.77)\end{array}$ & $\begin{array}{l}-0.87 \\
(0.80)\end{array}$ & $\begin{array}{l}0.41^{* *} \\
(0.17)\end{array}$ & $\begin{array}{l}0.65^{* *} \\
(0.23)\end{array}$ \\
\hline Angina & $\begin{array}{l}1.01 \\
(0.70)\end{array}$ & $\begin{array}{l}0.89 \\
(0.74)\end{array}$ & $\begin{array}{l}1.47^{*} \\
(0.80)\end{array}$ & $\begin{array}{l}1.37^{*} \\
(0.83)\end{array}$ & $\begin{array}{l}0.09 \\
(0.21)\end{array}$ & $\begin{array}{l}-0.09 \\
(0.27)\end{array}$ \\
\hline Kidney & $\begin{array}{l}-0.73 \\
(1.12)\end{array}$ & $\begin{array}{l}-0.55 \\
(1.34)\end{array}$ & $\begin{array}{l}-0.34 \\
(1.24)\end{array}$ & $\begin{array}{l}0.01 \\
(1.26)\end{array}$ & $\begin{array}{l}0.70^{* *} \\
(0.25)\end{array}$ & $\begin{array}{l}1.02^{* *} \\
(0.39)\end{array}$ \\
\hline Contbow & $\begin{array}{l}1.02^{*} \\
(0.60)\end{array}$ & $\begin{array}{l}0.84 \\
(0.64)\end{array}$ & $\begin{array}{l}1.06 \\
(0.86)\end{array}$ & $\begin{array}{l}0.98 \\
(0.89)\end{array}$ & $\begin{array}{l}-0.49 \\
(0.31)\end{array}$ & $\begin{array}{l}-0.72^{*} \\
(0.40)\end{array}$ \\
\hline Stroke & $\begin{array}{l}-0.07 \\
(0.57)\end{array}$ & $\begin{array}{l}-0.06 \\
(0.58)\end{array}$ & $\begin{array}{l}0.40 \\
(0.68)\end{array}$ & $\begin{array}{l}0.51 \\
(0.69)\end{array}$ & $\begin{array}{l}0.40^{* *} \\
(0.16)\end{array}$ & $\begin{array}{l}0.56^{* *} \\
(0.20)\end{array}$ \\
\hline
\end{tabular}

NOTE: Standard Errors in Parentheses

** $(*)$ indicates statistical significance at the 5\% (10\%) level. 
Figure 1- Living Arrangement Histories for Fathers

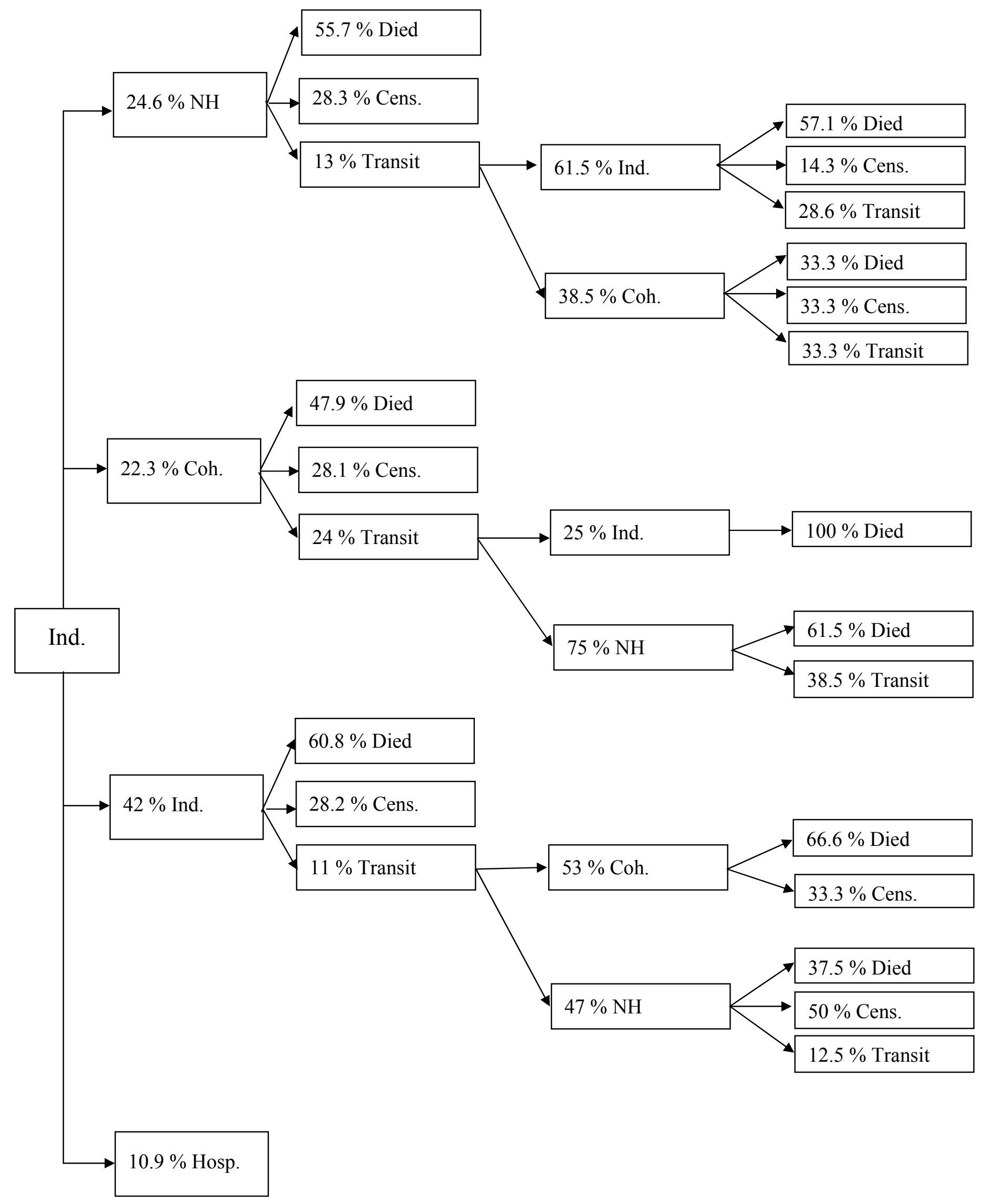


Figure 2 - Living Arrangement Histories for Mothers

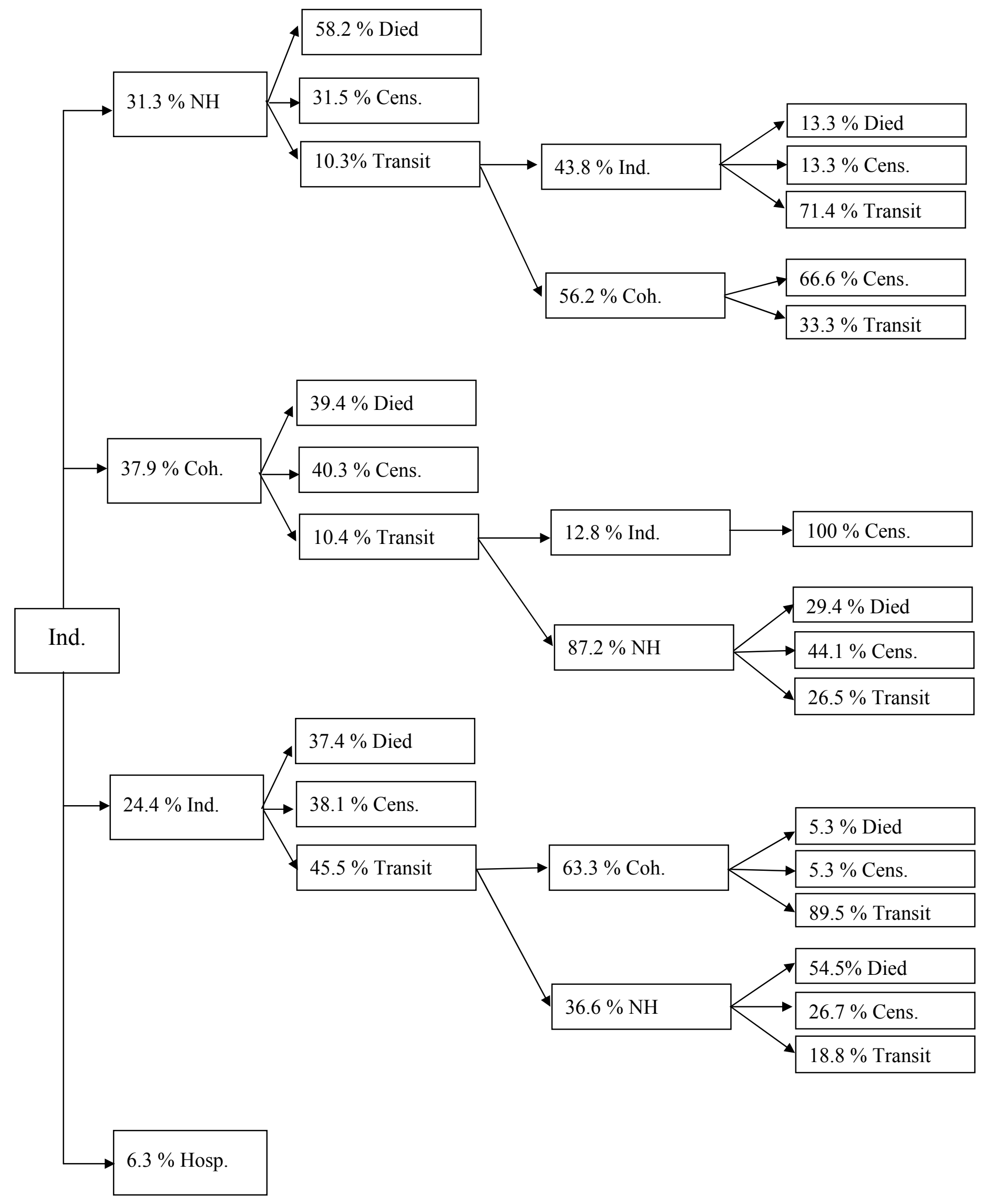

